DOI: $10.7242 / 2658-705 X / 2020.1 .9$

УДК 39 (397.4)

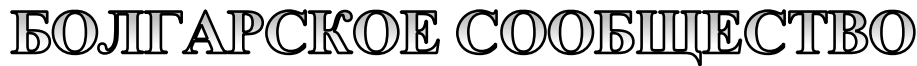

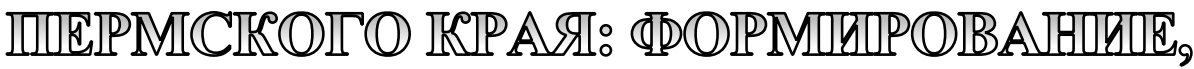

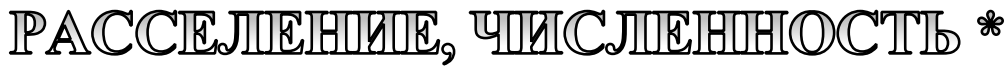

\begin{abstract}
А.В. Черных, Пермский федеральный исследовательский центр УрО РАН
В.Л. Кляус, Институт мировой литературы им. А.М. Горького РАН

М.П. Кляус, Институт этнологии и антропологии им. Н.Н. Миклухо-Маклая РАН

М.С. Каменских, Пермский федеральный исследовательский центр УрО РАН
\end{abstract}

Статья посвящена истории формирования, анализу миграций и характеру расселения болгарского сообщества в Пермском крае в XX веке. Этнодисперсная группа болгар в Урало-Поволжском регионе сформировалась в результате ряда регулируемых государством переселенческих кампаний. Анализ архивных материалов Пермского государственного архива социальнополитической истории показывает, что большинство болгар оказались в регионе в результате принудительного выселения (раскулачивание, депортация) с территории УССР, МССР и Крымской АССР и лишь несколько человек были политическими эмигрантами из самой Болгарии.

Кроме архивных документов использованы материалы интервью, содержащие воспоминания болгар о жизни в Пермском крае.

Ключевые слова: болгары, этнодисперсная группа, этнодемографические процессы, численность, депортация, раскулачивание, Прикамье, Пермский край.

Пермский край - один из центральных субъектов российского УралоПоволжского региона. Находясь на границе Европы и Азии, он во многом характеризует процессы, происходящие в территориях Урала и Сибири.

Границы Пермского края в основном охватывают территорию Прикамья - исторически сложившегося региона западной части Среднего Урала. Административные границы региона в XX веке неоднократно менялись: до 1923 года в Прикамье входили Пермский, Оханский, Чердынский, Кунгурский, Осинский, Соликамский и Красноуфимский уезды Перм- ской губернии; в 1923-1934 годах территории Верхнекамского, Коми-Пермяцкого, Кунгурского, Пермского и Сарапульского округов Уральской области; Пермского округа Свердловской области в 1934-1939 годах; Пермской области, с 2005 года - Пермского края.

Прикамье исторически формировалось как регион трансграничных миграций. В XIX-XX веках помимо традиционно компактно проживавших здесь народов (русские, татары, башкиры, марийцы, удмурты, коми- пермяки, манси) в Прикамье в силу разных исторических причин сформировались и этнолокальные группы

* Исследование выполнено в рамках проекта РФФИ №19-59-18003 «Болгары Урала и Сибири в XX-XXI веках: история, культура, идентичность». 
некоренного населения - поляки, немцы, евреи, украинцы, белорусы, латыши, китайцы, корейцы и др. В середине второй половине XX века численность населения Прикамья резко возросла за счет регулируемых государством переселенческих кампаний из разных районов страны [27, с. 46-67]. Одной из таких этнодисперсных групп стали болгары, анализу миграции и характеру расселения которых посвящена данная статья.

В Прикамье, как и в Урало-Сибирском регионе, болгары появились только в ХХ веке. Численность болгар Российской Империи в конце XIX века составляла 172659 человек, или 0,14 населения. На тот момент компактные места проживания болгар были расположены далеко за пределами Урало-Сибирского региона: в Херсонском, Тираспольском и Одесском уездах Херсонской губернии, в Аккерманском, Измаильском, Бендерском уездах Бессарабской губернии, а также в Феодосийском, Бердянском и Мелитопольском уездах Таврической губернии (совр. Крым и Приазовье) [1, с. 10]. Появление болгар на территории Пермской губернии по выявленным к настоящему времени источникам, фиксируется только в конце XIX в. Если Однодневная перепись жителей г. Перми 1890 г. не фиксирует болгар среди населения города $[25$, с. 36$]$, то уже в материалах Первой всеобщей переписи населения Российской империи 1897 г. болгары отмечены среди многонационального сообщества Пермской губернии как жители разных городов и уездов. Всего в Пермской губернии в 1897 г. проживало 9 человек, указавших на болгарский язык в качестве родного, среди них 5 женщин и 4 мужчины. Пермские болгары в конце XIX составляли менее $0,01 \%$ от болгар России. Наибольшее число болгар Пермской губернии было отмечено в Красноуфимском уезде - 3 мужчины и 1 женщина, в Шадринском уезде проживало 2 болгарки, 1 болгарин отмечен в материалах перепи- си в Осинском уезде. В г. Перми численность болгар составила 2 человека, обе женщины [12, с. 94-95].

Первая советская перепись населения 1920 года зафиксировала проживание на Урале 38 болгар, большая часть из которых, 28 человек, размещалась на территории Челябинского и Троицкого округов (в границах 1923 года). Учитывая, что именно в эти местности вначале XX в. приезжало большое количество переселенцев с Украины, справедливо предположить, что эти болгары также являлись переселенцами из районов Причерноморья. Переселенческий статус болгар данного периода косвенно подтверждает и тот факт, что 29 из них были мужчинами. Собственно в Пермском округе в 1920 году проживало 3 болгарина. Об их занятиях и социальном статусе ничего неизвестно [24, с. 34-35]. Они говорили на родном языке и не были грамотны по-русски [3, с. 124].

К 1930-м годам, когда социальная мобильность населения в рамках границ СССР значительно возросла, Урал стал одним из мест распределения избытков населения из центральных и южных районов страны. Миграции конца 1920-х - начала 1930-х годов значительно усложнили этнический состав населения Урала, а вместе с ним и Прикамья. Всесоюзная перепись населения 1939 года зафиксировала проживание в области 146 болгар, большинство из которых оказались в Прикамье в результате компаний по раскулачиванию. В конце 1930-х годов, как показала перепись, болгары не проживали только в 6 из 42 районов области, а больше всего их было в Добрянском районе - 33 человека, в Перми проживало 6 болгар [4].

По остальным районам области болгары распределились следующим образом: Чусовской горсовет - 12, Чердынский район - 11 , Соликамский район - 9, КомиПермяцкий национальный округ -8 , Чернушинский район - 7, Бардымский район -5 , Осинский район -4 , Кизелов- 
ский горсовет - 3, Куединский район - 3, Очерский район - 3, Сивинский район - 3 , Уинский район - 3, Щучье-Озерский - 3, Березовский район - 2, Верхне-Муллинский район -2 , Ворошиловский район -2 , Суксунский район - 2, Частинский район - 2, Черновский район - 2, Лысьвенский горсовет -1 , Еловский район -1 , Кишертский район - 1, Ординский район - 1, Фокинский район - 1 [4].

Наличие мест компактного проживания в районах больших строек, безусловно, свидетельствует о последствиях принудительного выселения, в то время как дисперсный характер расселения большей части болгар - о серьезных процессах добровольной миграции и социальной мобильности в болгарском социуме советского периода. К сожалению, об их занятиях и социальном статусе пермских болгар того периода практически ничего неизвестно. Однако в Пермском государственном архиве социально-политической истории (ПермГАСПИ) хранится свыше 50 дел о болгарах Прикамья 1930-х годов, которые позволяют частично реконструировать их облик и род занятий. Так, одной из причин появления болгар в Перми и Прикамье была политическая эмиграция. К примеру, уроженец с. Ново-Махла Хармаильского района Болгарии, член ВКП (б) Георгий Маркович Бойдев оказался с женой в СССР в результате политической эмиграции в 1929 году. В Прикамье в начале 1930-х годов он был заместителем заведующего цеха Вишерского комбината [16].

Болгары, переехавшие в СССР, жили в Перми и трудились на Заводе № 172 им. В.М. Молотова (совр. «Мотовилихинские заводы). Самым известным из них был Георгий Иванович Дубов, родившийся в болгарском с. Белотынцыв в 1894 году. В годы Первой мировой войны он служил поручиком в болгарской армии, был активистом коммунистического движения и членом Болгарской коммунистической партии
(БКП). За политическую деятельность на родине он был приговорен к смертной казни, эмигрировал в СССР в 1924 году, получил советское гражданство и вступил в ряды ВКП (б). По профессии он был артиллеристом, на заводе работал начальником отдела технического контроля. Был женат, имел двух сыновей [13]. Его соотечественник болгарин Терзеев Степан Иванович работал в Перми завхозом здравпункта завода № 172. О времени его приезда данных не сохранилось, но известно, что он родился в с. Гурково Болгарии в 1896 году и имел профессию сапожника, а в 1920-е годы получил советское гражданство и взял себе фамилию Портнов [15]. Кроме Г.И. Дубова и С.И. Терзеева в документах существуют сведения о других болгарах, работавших на заводе № 172 [13].

Однако большинство болгар, попавших в Прикамье в 1930-е годы, были рождены в России. В Добрянском районе они проживали в поселках Верх. Исток и Ключанка. Большинство из них являлись уроженцами с. Парканы Тираспольского района Молдавской АССР. Они работали на лесозаготовках и на тракторной базе. В Перми в качестве трудармейца оказался Никушор Георгий Иванович, родившийся в Молдавской АССР. Известно, что он работал грузчиком, имел жену и сына [17]. В с. Никулино Добрянского района жил Георгий Маркович Груцанов. Он не имел образования и партийной принадлежности, на поселении работал трактористом, где, как и многие его земляки, оказался в результате раскулачивания [14].

В период Великой Отечественной войны Молотовская область стала одним из мест размещения греческого, армянского и болгарского населения полуострова Крым. Согласно постановлению Государственного комитета обороны от 2 июня 1944 года № ГОКО-5984 сс, в Молотовской области следовало разместить 10000 «немецких пособников из числа болгар, греков и армян» [23]. В результате более 
тысячи болгар с формулировкой «проживал на оккупированной территории» оказались на поселении в Прикамье, в основном в Чердынском, Красновишерском, Кизеловском районах и г. Березники.

Из опубликованных воспоминаний болгарина Георгия Мандычева: «Когда наш состав дотащился до Соликамска, мы поняли, что это еще не конец пути. Дальше нас погрузили на баржу, и по реке Вышере потащились мы еще на сотню километров в глубь тайги. Новую волну «врагов народа», нас встречали на пристани жители Красновишерска - в основном сосланные сюда еще в тридцатые годы так называемые кулаки. Многие из них отнеслись к нам сочувственно, что и помогло нам пережить первую, показавшуюся южанам невероятно суровой, зиму. Ни одежды, ни продуктов, ни надежной крыши над головой. С растерянными душами и растерзанными нервами начинали болгары новую жизнь на новом месте» [9, с. 4-5]. Для многих болгар переезд в более холодную климатическую зону стал настоящим шоком. «Запомнился путь по Уралу, - рассказывает Меланья Дучева, - когда нас, покрытых инеем, везли на огромных санях. По всем прикидкам, это было летом, самое позднее в конце июля. Но мы ехали в санях, которые тащил трактор, и очень мерзли. В таком краю мы, жители юга, очутились... » [10, с. 4-5].

Как и во времена царской России, советская власть депортацией, по сути, решала хозяйственно-экономические и демографические проблемы удаленных и малозаселенных регионов страны. Болгары, трудолюбие которых давно стало предметом шуток со стороны живущих рядом с ними в Крыму и Бессарабии народов, оказавшись в Пермском крае, немало сил вложили в его развитие и процветание. Они начали собственноручно обустраивать свои хозяйства, несмотря на бытовые сложности и законодательные ограничения. Георгий Мандычев продол- жает в своих воспоминаниях: «Видать, глубоко сидит в нашем народе эта способность выживания. Гнездится сила, позволяющая вновь и вновь нести свой тяжкий крест. Конечно, многие старики и дети не выдержали лишений, легли в наскоро вырытые могилы среди лесов и болот. Однако большинство выжило, вынесло и холод, и голод, и унизительное положение спецпоселенцев. Трудились, не покладая рук, все от мала до велика. Быстро сходились со старожилами» [9, с. 4-5].

Местное население, судя по воспоминаниям, отнеслось к болгарам сочувственно. Новым жильцам помогали обустроиться в первое время, а детей, оказавшихся на Урале без родителей, брали в приемные семьи: «Быстро сходились со старожилами. Завоевывали уважение своим трудолюбием и добросердечием. Местные учили болгар своему образу жизни, мы с ними делились нашим житейским опытом» [9, с. 4-5].

Поразительна судьба болгарской девочки Маши Стояновой. Историю матери рассказала ее дочь Людмила Антонюк: «Мама была в Коктебеле со своей родней, двоюродной сестрой, смотрела мальчика. Ее выслали с ними в Кизел. Ребенок, которого она смотрела, у него рахит - лишний рот никому не нужен. И они ей сказали: «Уж извини». Сорок четвертый, июль, Пермский край, два месяца ходила, выпал снег. Она говорит: «Я уже не могла!». Свиней кормили. Она увидела: женщина вышла и давала свиньям кушать. И она пришла туда, и эта женщина ее нашла, она была уже без сознания. И вот эта женщина забрала ее к себе, потому что поняла девчонка умирает. До сорок восьмого года, четыре года она с ней была. Марией ее звали. Фамилию она не помнит. И у нее свои дети были. Эта женщина стала писать, написала и Молотову, писала в правительство. Ее родителей, брата и сестру уже в Узбекистан высылали. Я так понимаю, что эта женщина вымолила их. И когда они приехали, я даже, - говорит - 
помню. Она кричит: «Машенька, Машенька! Посмотри, кто идет!». И идут - мать ее идет, все. Она говорит: «Я как закричала и потеряла сознание. Уже очнулась, эта женщина, Мария к себе взяла. Но потом вот в барак их поселили» [22].

К началу 1950-х годов болгары уже обжились на новом месте, создали собственные хозяйства, образовывали новые семьи, в том числе за счет межнациональных браков с местным населением [20]. Петр Федорович Писарогло, уроженец Молдавской АССР, оказался в Перми после высылки из родного села Ново-Тамай в возрасте 22 лет. На тот момент у него уже были жена и дочь. Он не имел образования и партийной принадлежности, работал рамщиком на заводе Вторчермета [18].

Петр Петрович Киров, известный скрипач и педагог, заслуженный работник культуры Автономной Республики Крым, свою карьеру профессионального музыканта также начинал в Перми, после окончания Пермского музыкального училища. O нем с большим теплом вспоминают многие крымчане, и не только болгары. Людмила Радева, дружившая с его семьей и неоднократно писавшая об этом музыканте-педагоге вспоминает: «Скрипачи все у нас в Крыму приходили к нему прослушиваться. Педагоги другие приводили: «Петр Петрович! Посмотрите!» [21].

Азы игры на скрипке Петр Петрович постигал самоучкой в детстве, и уже юношей славился среди крымских болгар хорошим музыкантом, играя на праздниках и свадьбах. В г. Кизеле Молотовской области он оказался в восемнадцать лет и сразу - на лесоповал. «Когда он на лесоповале работал, - продолжает свой рассказ Людмила Радева - там его свои же берегли, что ты - музыкант: полегче ему работу. А потом при клубе нужен был художник. Он же в художественном училище учился. Комендант взял к себе в клуб сначала именно как художника, а потом, когда узнал, что еще и му- зыкант, стал в этом качестве использовать. Потом предложил ему стукачом быть, но Петр Петрович отказался, и его отправили в столярную мастерскую. Вот тоже там его берегли наши болгары. Музыкального образования у него не было, и он решил поступать в Пермское училище. И когда комендант узнал, что Петр, оказывается, ездил в Пермь и поступил, раскричался! Хорошо, что его под суд не отдал, за это вообще двадцать лет каторги могли дать, что без разрешения покинул место проживания. Но он поступил уже! И его отправили в эту Пермь в сопровождении милиционера, там из рук в руки передали, в комендатуре на учет поставили, чтоб он учился. До этого, еще в сорок пятом году, из Симферополя приехала к нему девушка, она украинка была, как декабристка поехала за ним и замуж вышла. К пятьдесят первому, когда он пошел учиться, у них уже трое детей было. И он успевал учиться, а вечером играл в ресторанах, в кинотеатрах перед сеансами. Так он три курса музыкального училища окончил, а потом поступил в Пермскую консерваторию! С первого раза! Талант! Но консерваторию он бросил, учиться не смог - трое детей, нагрузки другие» [21].

После отмены режима на ограничение передвижения и снятия статуса спецпоселенцев большинство болгар вернулись на историческую родину. Сегодня большинство потомков пермских болгар проживает на территории Ставропольского и Краснодарского края, Республики Крым и на Украине. В семейных преданиях сохранилось немало воспоминаний о жизни родителей, бабушек и дедушек на Урале.

Болгарская песельница и поэтесса Г.И. Попова, находившаяся на поселении в г. Губахе, сочинила на народную мелодию несколько песен о жизни на Урале, где ничего не растет, передавала растерянность болгар, которые не были приспособлены жить в этом холодном крае: 
Ой, Слюмну ля, ой румяну, мъри, щза так ти рана стана, рано стана, та ни носиш лошав хъберь.

Че ни дигат от къщите, мъри, от къщите от топъл край.

Та ни карат на Уралът, мъри,

На Уральт и в Сибирят.

Та остана всичко живо, мъри,

Всичко живо и умряло.

Това край на нас бе страшен, мъри,

Че бе много там студено,

Че там нищу не растеше, мъри,

Не ябълки, не чуреши.

А пак ния сме българи, мъри,

И сме ния научени,

И сме ния научени, мъри

Да живеме в топло място.

Ние нищо не сторихме, мъри,

Да ни дигат от нашият Крим,

От нашият Крим, дет живяхме, мъри

Дет живяхме и пеяхме.

Но ние се дочакахме, мъри,

Дочакахме и дожихме,

Та се върнахме пак тука, мъри,

Да живяме и пяеме.

В песне переплетены разные исторические этапы: трагический отъезд из Крыма, жизнь на Урале и возвращение. Г.И. Попова подчеркивает, что на Урале болгары не просто ожидали, когда они смогут вернуться на родину, они смогли выжить.

В послевоенный период болгарское население Пермской области увеличивалось за счет обучающихся в вузах и отслуживших в армии советских болгар. В результате, по данным Всесоюзной переписи населения 1959 года, в Молотовской области проживало 1966 болгар (8\% всего болгарского населения РСФСР). Для 60\% пермских болгар родным языком был русский. В этот период Прикамье было одним из лидеров среди регионов страны по численности болгарского населения [8, с. 1].

В последующих переписях населения ввиду естественной убыли, отсутствия новых миграций и реэмиграции на историческую родину, а также ассимиляционных процессов численность болгар постепенно снижалась. Так, в 1970 году Всесоюзная перепись зафиксировала в Пермской области 897 болгар (сокращение на 55\%), что составляло $3,3 \%$ от их численности в РСФСР,
Ой, Слюмну, ой, румяная,

Почему ты так рано встала,

Рано встала и принесла нам плохую весть,

Что нас гонят из дома,

Из дома, из тёплого края.

И везут нас на Урал,

На Урал и в Сибирь.

И оставляем всю живность,

Всю живность и умерших.

Тот край для нас был страшен,

Потому что там было очень холодно,

Потому что там ничего не росло,

Ни яблоки, ни черешня.

A мы все же болгары,

И мы приучены,

И мы приучены

Жить в тёплом месте.

Мы ничего не сделали,

Чтобы нас выгнали из натего Крыма

Из намего Крылма, где жили,

Где жили и пели.

Но мы дождались,

Дождались и дожили,

Чтобы вернуться снова сюда,

И жить и петь. [7, с. 249].

в то время как в РСФСР, в целом, численность болгар росла. Интересно проследить и данные о языке, поскольку в 1970 году в переписях впервые был задан вопрос о втором языке. Русский язык родным в 1970 году назвали 60\% пермских болгар (доля сохранилась несмотря на сокращение численности). Вторым языком для болгар в Перми был русский, на это указали $37 \%$, т.е. практически все болгары, для которых болгарский язык был родным, свободно владели и русским языком.

В 1979 году численность болгар в Прикамье вновь снизилась до 741, или, примерно, 3\% всех болгар РСФСР [5]. Обозначившиеся процессы отрицательной динамики сохранились и в 1989 году, когда численность болгар составила уже 681 (0,02\% от населения области). Болгары продолжали оставаться преимущественно городским населением (86\%), сохранялся и относительный гендерный баланс: 382 мужчины и 289 женщин. Всего в РСФСР в 1989 году проживало 32785 болгар, что на 25\% выше уровня 1959 года (24 899 человек) [6]. То есть в целом по стране болгарское население росло, что косвенно свидетельствует о 
влиянии, в первую очередь, реэмиграционных процессов на динамику болгарского населения Прикамья. Пермские болгары в 1989 году составляли уже 2\% всех болгар РСФСР, 20\% указали болгарский язык в качестве родного, для остальных родным языком был русский [19].

В постсоветский период было проведено еще две переписи населения, каждая из которых фиксировала постепенное сокращение численности болгарского населения в Прикамье. Кроме этого, опубликованные данные позволяют проанализировать как языковые процессы, так и характер расселения болгарского населения. Так, в 2002 году в Прикамье проживало 502 болгарина, в том числе $274(55 \%)$ мужчины и 228 $(45 \%)$ женщин. Болгары жили в Перми 155 , Соликамске - 56, Губахе - 37, Березниках - 25, Краснокамске - 23, Красновишерском районе - 23, Александровске - 17, Кунгуре - 17, Чусовом - 13, Пермском районе - 12, Чердынском районе - 12, Чайковском - 11, Добрянке - 11, Гремячинске - 10, Кизеле - 7, Лысьве - 6, Сивинском районе - 6, в остальных территориях - менее 5. При этом проживание болгар зафиксировано во всех районах Пермской области, за исключением Кунгурского, Частинского и Усольского.

В целом можно отметить, что болгары были расселены в 2002 году довольно дисперсно, наибольшее количество проживало в крупных населенных пунктах, компактных мест расселения не выявлено. В 2002 году болгары Прикамья составляли уже менее $2 \%$ всех российских болгар, хотя в этом же году впервые было зафиксировано сокращение болгарского населения по сравнению с предыдущей переписью на 2,5\%, что все равно меньше, чем убыль населения в целом по России. Другими словами, можно предположить, что ассимиляционные процессы практически не коснулись российских болгар во второй половине XX века. Доля владеющих родным языком болгар в 2002 году составила лишь 14\% от общего количества, причем у женщин процент сохранивших болгарский язык был выше, чем у мужчин (табл. 1).

Наиболее актуальные данные о численности болгарского населения в Прикамье демонстрируют итоги Всероссийской переписи населения 2010 года. По итогам переписи, численность болгар в Прикамье уменьшилась практически вдвое и составила 286 человек, что было чуть более $0,01 \%$ от численности населения Пермского края и примерно 1,2\% от всех болгар России. Болгары имеют довольно высокий уровень урбанизации: $79,1 \%$ - в России и $85,7 \%$ - в Пермском крае. Местами проживания наибольшего количества болгар в Пермском крае также являются города - северные районы, где проживают потомки репрессированных: Пермь - 86, Соликамск - 36, Губахинский район - 24, Красновишерский район - 16, Александровский район - 13, Кунгур - 11, Березники - 11, в остальных менее 10 [2].

Таблища 1

Болгары в Российской Федерации и Пермском крае по итогам Всероссийской переписи населения 2002 года

\begin{tabular}{|l|c|c|c|c|}
\hline \multicolumn{1}{|c|}{ Численность болгар } & РФ & $\begin{array}{c}\text { Процент от общей } \\
\text { численности } \\
\text { болгар России }\end{array}$ & $\begin{array}{c}\text { Пермский } \\
\text { край }\end{array}$ & $\begin{array}{c}\text { Процент от общей } \\
\text { численности } \\
\text { болгар Прикамья }\end{array}$ \\
\hline Общая численность & 31965 & 100 & 502 & 100 \\
\hline Из них владеют болгарским языком & н/д & н/д & 72 & 14,3 \\
\hline В том числе мужчин & 17281 & $54 \%$ & 274 & 55 \\
\hline Из них владеют болгарским языком & н/д & H/д & 36 & 7,2 \\
\hline В том числе женщин & 14684 & 46 & 228 & 45 \\
\hline Из них владеют болгарским языком & н/д & н/д & 36 & 7,2 \\
\hline
\end{tabular}


Среди болгарского населения России на протяжении всего XX века численность мужчин превышала женскую, хотя это не характерно для демографических процессов в России. Даже в 2010 году, несмотря на тенденцию к увеличению доли женщин в общей численности болгарского населения, количество мужчин все равно превышало число женщин как среди городского, так и среди сельского населения. Эта ситуация характерна и для Прикамья, но последняя перепись уже зафиксировала превышение числа женщин по отношению к мужчинам в сельской среде.

Большинство болгар России указали, что владеют русским языком (99,6\%), болгарский язык в качестве родного при этом отметили 8157 переписанных граждан, из них болгар - не менее 7500 , или $32 \%$, в Пермском крае - 16,4\% [2]. Помимо болгар болгарский язык распространен среди русских, украинцев и молдаван.

В целом, социально-демографические характеристики болгар России совпадают

с ситуацией в болгарской среде Прикамья. Пермских болгар отличает немного более высокий уровень городского населения и более слабое сохранение родного языка (табл. 2).

Не удивительно, что большинство потомков болгар, выросших или родившихся в депортации, не знают болгарского языка. Это обусловлено тем, что в сложнейших условиях жизни родители, испытывая страх за детей, понимали, что из-за клейма социально опасных, они могли быть ограничены в доступности образования и подвержены унижениям со стороны сверстников. Родители старались не учить детей болгарскому языку и при возможности (в случае межэтнических браков) меняли болгарские фамилии детей на русские, белорусские и др.

Собственно в городе Перми численность болгар края незначительна. В городе проживает 86 болгар (в Пермском крае 286), большая часть их них - в Свердловском и Индустриальном районах (табл. 3).

Таблий 2

Болгары в Российской Федерации и Пермском крае по итогам Всероссийской переписи населения 2010 года

\begin{tabular}{|l|c|c|c|c|}
\hline \multicolumn{1}{|c|}{ Численность болгар } & РФ & $\begin{array}{c}\text { Процент от общей } \\
\text { численности } \\
\text { болгар России }\end{array}$ & Пермский край & $\begin{array}{c}\text { Процент от общей } \\
\text { численности } \\
\text { болгар Прикамья }\end{array}$ \\
\hline Общая численность & 24038 & 100 & 286 & 100 \\
\hline В том числе мужчин & 12807 & 53,3 & 159 & 56 \\
\hline В том числе женщин & 11231 & 46,7 & 127 & 44 \\
\hline Городское население болгар & 19021 & 79,1 & 245 & 85,7 \\
\hline В том числе мужчин & 10263 & 42,6 & 140 & 49 \\
\hline В том числе женщин & 8758 & 36,3 & 41 & 105 \\
\hline Сельское население болгар & 5017 & 20,9 & 19 & 6,7 \\
\hline В том числе мужчин & 2544 & 10,6 & 22 & 7,7 \\
\hline В том числе женщин & 2473 & 10,3 & \\
\hline
\end{tabular}

Численность болгар города Перми по итогам 2010 года

Таблиия 3

\begin{tabular}{|c|c|c|c|c|}
\hline \multirow{2}{*}{ Район проживания } & \multirow{2}{*}{ Численность болгар } & \multicolumn{3}{|c|}{ В том числе с родным языком } \\
\hline & & болгарским & русским & Другое \\
\hline г. Пермь & 86 & 13 & 70 & 3 \\
\hline Дзержинский & 13 & 1 & 12 & - \\
\hline Индустриальный & 19 & 3 & 16 & - \\
\hline Кировский & 4 & - & 4 & - \\
\hline Ленинский & 11 & 4 & 4 & 3 \\
\hline Мотовилихинский & 9 & 1 & 8 & - \\
\hline Орджоникидзевский & 6 & - & 6 & - \\
\hline Свердловский & 24 & 4 & 20 & - \\
\hline
\end{tabular}


Для 92\% пермских болгар родным языком является русский [26, с. 33].

Сегодня в Прикамье, несмотря на малочисленность, болгары являются узнаваемыми в социокультурном пространстве, среди них немало представителей интеллигенции, болгарская культура, туризм в Болгарии также являются весьма популярными у жителей Пермского края. Развиваются и деловые связи. Так, Пермская торгово-промышленная палата имеет собственное представительство в странах Балканского региона, в крае работает болгарская фирмы «Артела», оказывающая услуги «поиска партнеров для совместного производства в Болгарии, покупателей российских товаров в Болгарии, поставщиков болгарских товаров в РФ» [11]. История болгар уже становилась объектом исследования местных историков. В 2018 году в рамках издательского проекта «Народы Перми: история и культуры» научным коллективом отдела истории, археологии и этнографии Пермского федераль- ного исследовательского центра УрО РАН издана монография «Болгары Перми: история и культура». При этом в Прикамье не создано отдельной болгарской организации, которая объединяла бы представителей данного этноса.

Болгары Прикамья являются одной из этнодисперсных групп болгар Урало-Поволжского региона России, для них характерны этнодемографические процессы, свойственные российским болгарам в целом. Среди особенностей болгарской миграции можно назвать ее волновой характер, дисперсный характер расселения болгар. Важной чертой миграции является и тот факт, что хронологически она охватывает только период XX века. Несмотря на относительную «краткосрочность» пребывания в регионе, болгары успели сформироваться как отдельная этнодисперсная группа, обладающая своими особенностями и региональной спецификой, выделяющей болгар Урала и Сибири в отдельную группу российских болгар.

\section{Библиографический список}

1. Болгары // Алфавитный список народов, обитающих в Российской Империи. - СПб., 1895. - С. 10-11.

2. Всероссийская перепись населения 2010. Т. 4. Национальный состав и владение языками, гражданство [Электронный ресурс]: Росстат. https://gks.ru/free_doc/new_site/perepis2010/croc/perepis_itogi1612.htm (дата обращения: 01.11.2019).

3. Всесоюзная перепись населения 1926 г. [Текст]: T. IV. Воткинский р-н, Уральская обл., Башкирская АССР. Отд. І. - М.: Изд. ЦСУ Союза ССР, 1928. - 428 с.

4. Всесоюзная перепись населения 1939 года. Национальный состав населения районов, городов и крупных сел РСФСР [Электронный pecypc]: ДемоскопWeekly. URL. http://demoscope.ru/weekly/ssp/rus_nac_39_ra.php?reg=1097 (дата обращения 10.11.2019).

5. Всесоюзная перепись населения 1979 года. Национальный состав населения по регионам России [Электронный ресурс]: Росстат. URL.: http://www.demoscope.ru/weekly/ssp/rus_nac_79.php (дата обращения: 01.11.2019).

6. Всесоюзная перепись населения 1989 года.Национальный состав населения по регионам России [Электронный ресурс]: Росстат. URL.: http://www.demoscope.ru/weekly/ssp/rus_nac_89.php?reg=0 (дата обращения: 01.11.2019).

7. Гайворонская О.Б. Тема депортации в устном народном творчестве болгар Крыма // Этнография Крыма XIX-XXI вв. и современные этнокультурные процессы: Материалы и исследования. Вып. 2. Симферополь, 2012. - С.242-252.

8. Государственный архив Пермского края (ГАПК). Ф. р-493. Оп. 19. Д. 22.

9. Зачем и за что // Извор. - 2004. - № 12 (66). - С. 4-5.

10. Митрохин В. Живица или долгая дорога домой // Извор. - 2003. - № 6 (60). - С. 4-5

11. ООО «АРТЕЛА» [Электронный ресурс]. URL.:http://permtpp.ru/members/konsaltingovye_yuridicheskie_uslugi_uslugi_eksperta/artela/_ (дата обращения: 10.11.2019).

12. Первая всеобщая перепись населения Российской империи 1897 года. Вып. 29-32. Губернии: Орловская, Пензенская, Пермская, Подольская. - СПб.: издание Центрального статистического комитета Министерства внутренних дел, 1904. Т. XVI. - С. 94-95. 
13. Пермский государственный архив социально-политической истории (РГАСПИ). Ф. 641/1. Оп. 1. Д. 10059. Дубов Георгий Иванович.

14. ПермГАСПИ. Ф. 641/1. ОП. 1. Д. 11293. Груцанов Георгий Маркович.

15. ПермГАСПИ. Ф. 641/1. ОП. 1. Д. 9164. Портнов Степан Иванович (Терзеев С.И.).

16. ПермГАСПИ. Ф. 643/2. Оп. 1. Д. 28312. Бойдиев Георгий Маркович.

17. ПермГАСПИ. Ф. 643/2. ОП. 1. Д. 24354. Никушор Георгий Иванович.

18. ПермГАСПИ. Ф. 643/2. ОП. 1. Д. 25382. Писарогло Петр Федорович.

19. Пермьстат. Всесоюзная перепись населения 1989 года. Пермская область.

20. Полевые материалы авторы (ПМА). Нечаева И., Симферополь, 2018.

21. ПМА. Радева Л. Симферополь, 2018.

22. ПМА. Антонюк Л. Симферополь, 2018.

23. Постановление ГОКО 5984 с «О выселении с территории Крымской АССР болгар, греков и армян» [Электронный ресурс]: Фонд Александра Н.Яковлева. URL. http://www.alexanderyakovlev.org/fond/issuesdoc/1022354 (дата обращения: 12.05.2018).

24. Уральский статистический ежегодник 1923-1924 гг. / Сер. 1. Т. 1. / под ред. В.С. Немчикова, П.Ф. Неволина. - Свердловск: Изд-во Уральского областного исполнительного комитета, 1925. - 200 с.

25. Чагин Г.Н., Черных A.B. Народы Прикамья: Очерки этнокультурного развития в XIX - XX вв. Пермь: Типография купца Тарасова, 2002. - 304 с.

26. Черных А.В., Каменских М.С. Болгары Перми: история и культура. - СПб.: Маматов, 2018. - 64 с.

27. Черных А.В., Каменских М.С., Белавин А.М. Этническая история Пермского края // Народы Пермского края: этническая история и современное этнокультурное развитие. - Словарьсправочник. - СПб.: Маматов, 2014. С. 46-67.

\title{
THE BULGARIAN COMMUNITY OF THE PERM REGION: FORMATION, SETTLEMENTS, NUMBER
}

\author{
A.V. Chernykh ${ }^{1}$, V.L. Klyaus ${ }^{2}$, M.P. Klyaus ${ }^{3}$, M.S.Kamenskikh ${ }^{1}$ \\ ${ }^{1}$ Perm Federal Research Centre UB RAS \\ ${ }^{2}$ A.M. Gorky Institute of World Literature of the RAS \\ ${ }^{3}$ The Russian Academy of Scieces N.N. Miklouho-Maklay Institute of Ethnology and Anthropology RAS
}

The article is devoted to the consideration of formation, migrations analysis and the nature of the settlement of the Bulgarian community in the Perm Region in the $20^{\text {th }}$ century. The ethnically dispersed group of Bulgarians in the Ural-Volga region was formed as a result of a number of stateregulated resettlement campaigns. The analysis of the archival materials of the Perm State Archive of Social and Political History shows that most of the Bulgarians moved to the region as a result of forced evictions (dispossession, deportation) from territories of the Ukrainian SSR, Moldavian SSR and the Crimean ASSR, and only a few people turned out to be political emigrants from Bulgaria. In addition to archival documents, the article also contains interview materials of memories of Bulgarians concerning life in the Perm Region.

Keywords: Bulgarians, ethnically dispersed group, ethno-demographic processes, number, deportation, dispossession, Prikamye, the Perm Region.

\section{Сведения об авторах}

Черных Александр Васильевич, доктор исторических наук, член-корреспондент РАН, заведующий сектором этнологических исследований отдела истории, археологии и этнографии, Пермский федеральный исследовательский центр УрО РАН (ПФИЦ УрО РАН), 614990, г. Пермь, ул. Ленина, 13A; e-mail: atschernych@yandex.ru

Кляус Владимир Леонидович, доктор филологических наук, заведующий отделом фольклора, Институт мировой литературы им. А.М. Горького РАН (ИМЛИ РАН), 121069, г. Москва, ул. Поварская 25A; e-mail: v.klyaus@mail.ru

Кляус Марина Петровна, кандидат исторических наук, научный сотрудник центра европейских исследований Института этнологии и антропологии им. Н.Н. Миклухо-Маклая РАН (ИЭА РАН), 119334, г. Москва, Ленинский проспект, 32A; e-mail: marina_klyaus@mail.ru

Каменских Михаил Сергеевич, кандидат исторических наук, старший научный сотрудник, Отдел истории, археологии и этнографии, ПФИЦ УрО РАН; e-mail: pomidorrr@mail.ru 